\title{
Many Rivers to Cross: Evaluating the Benefits and Limitations of Strategic Environmental Assessment for the Koshi River Basin
}

King, $\mathrm{H}$ and Smith, L.E.D., SOAS, University of London , accepted 1st February 2016, JEAPM

\begin{abstract}
This paper assesses the value of using Strategic Environmental Assessment (SEA) to account for the spatially and temporally diverse and diffuse potential impacts of hydropower development in South Asia's Koshi basin. A policy and practice review and key stakeholder interviews identified opportunities for SEA to improve existing planning procedures, but also barriers to effective adoption. Whilst stakeholders are interested in employing SEA to evaluate cumulative impacts, institutional blockages and an economic development imperative for power generation leave little space for consideration of alternative scenarios as part of SEA. The analysis is conducted through the formulation and application of a conceptual framework for SEA best practice which is then used to identify priority next-steps for a more dynamic application of SEA in the region.
\end{abstract}

\section{Introduction: Hydropower on the Koshi}

South Asia's Koshi River basin is the largest in Nepal, a significant tributary to the Ganges and home to over 30 million largely impoverished people. Like many Himalayan basins, The Koshi offers unrealised potential for hydropower development, with only 3 of over 50 potential installations having been completed in the past 30 years. (Figure 1, Table 1) (JICA 1985, ICIMOD 2015). 


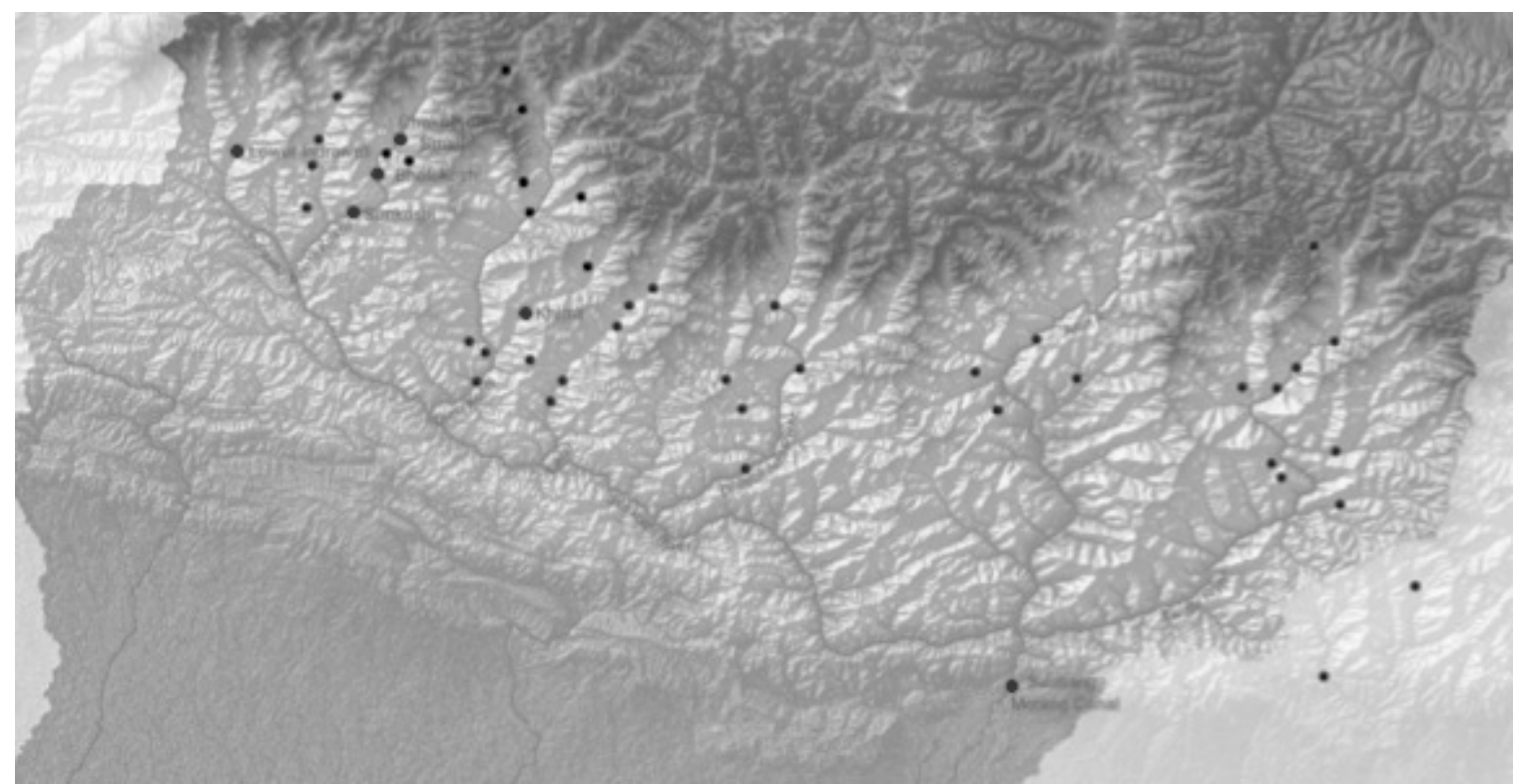

Figure 1: map of the Koshi Basin indicating current and planned hydropower stations (adapted from ICIMOD 2012).

As the region faces growing energy deficits a 'power imperative' has directed policy making towards the facilitation of major hydropower projects on the Koshi, with a view to driving Nepal's development through the net export of power to India.

\begin{tabular}{l|lllll} 
& $\begin{array}{l}\text { Potential } \\
\text { National } \\
\text { Capacity (MW) }\end{array}$ & $\begin{array}{l}\text { Economically } \\
\text { Feasible } \\
\text { Capacity (MW) }\end{array}$ & $\begin{array}{l}\text { Current } \\
\text { Installed } \\
\text { (MW) }\end{array}$ & $\begin{array}{l}\text { \% Of potential } \\
\text { capacity } \\
\text { undeveloped }\end{array}$ & $\begin{array}{l}\text { Target } \\
\text { Capacity } \\
\text { (MW) }\end{array}$ \\
\hline India & - & $\begin{array}{l}\text { (44,586 (118,210 } \\
\text { in Himalayas) }\end{array}$ & 39,339 & $72.8 \%$ & $\begin{array}{l}61,339 \\
\text { (by 2022) }\end{array}$ \\
Nepal & 83,000 & 42,000 & 636 & $98 \%$ & $\begin{array}{l}25,000 \\
\text { (by 2030) }\end{array}$ \\
$\begin{array}{l}\text { Koshi } \\
\text { Basin }\end{array}$ & - & 10,860 & 118 & $99 \%$ & 10,860
\end{tabular}

Table 1: Regional outline of actual and potential hydropower capacity (WECS 2010, CEA 2012)

Hydropower development on such a scale presents a range of well-documented risks, including reductions in food security, ecosystem services and hazard resilience for lowincome rural communities (WCD 2000). Strategic Environmental Assessment (SEA) has emerged as a tool for capturing the diverse and synergistic impacts of numerous hydropower projects and identifying sustainable outcomes for basins which are undergoing development (Andrade and Dos Santos 2015, Dusik et al 2003, Erlewein 2013, Fischer et al 2014, Hirji and Davis 2009). Whilst increasingly dynamic in many 
other areas, development and application of Environmental Assessment (EA) approaches has been considered limited and slow in the Koshi region. Environmental Impact Assessments (EIAs) are mandatory for larger projects but supplementary guidelines still struggle to handle second-generation EA issues of risk, scale, distribution and institutional regulation (Bragagnolo et al 2012, Erlewein 2013, Tetlow and Hanusch 2012). This paper therefore aims to evaluate the opportunities and barriers for SEA to improve strategic level planning in the relatively new context of Koshi hydropower development.

\section{Methodology}

The nascent development of the discipline in Nepal meant that it was not possible to establish the status of SEA related practices by reviewing pre-existing reports against set criteria (Fischer 2010, Fischer and Phylip-Jones 2015). Furthermore, the complex and flexible nature of strategic level decisions merit a broader investigative approach in order to capture the informal issues and learning processes present behind official policy (Cherpa et al 2007, Fischer and Onyango 2012, Gazola et al 2011, Jha-Thakur et al 2009). This review therefore aimed to ascertain to what extent existing EA systems meet SEA best practice through the combination of a document review and interviews with key stakeholders (Acharibasama and Noblea 2014).

To reflect the flexible nature of SEA as a tool (Dalal-Clayton and Sadler 2005, Lobosa and Partidario 2014) a conceptual framework of Koshi-relevant SEA best practice was critically drawn from the World Commission on Dam's strategic priorities (WCD 2000), the EU SEA Directive (2001), the IAIA SEA principles (2002) and the OECD's SEA guidelines (2006). Specialist literature, such as the Hydropower Sustainability 
Assessment Protocol (2011), was discounted due to its limited scope or project-level focus.

Four elements of SEA were critically identified as being key for its effective application to hydropower in the Koshi, these are:

- The consideration of developments' cumulative impacts.

- The consideration of alternative approaches to meeting energy demand.

- Strong institutional accountability in development decisions.

- An iterative approach to reviewing the effectiveness of past decisions.

In order to provide a fuller description of what best practice in the Koshi Basin would 'look like' the main features of each key element were then defined. Each feature was assigned qualitative indicators for example, 'transparent decision making between alternative development options' would be indicated by use of the precautionary principle and a mitigation hierarchy, consideration of the distribution of benefits and the commitment to an equal three 'pillars' approach to sustainability. As a whole, the key features and indicators of each element provide a conceptual framework (CFW) of best practice against which to assess current and potential practice (Table 2).

\begin{tabular}{|c|c|c|}
\hline & Key Features & Qualitative Indicators \\
\hline \multirow{7}{*}{ 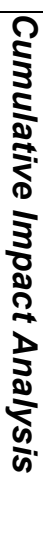 } & \multirow{3}{*}{$\begin{array}{l}\text { Objectives correlate } \\
\text { with relevant spatial } \\
\text { and temporal scale } \\
\text { of impacts and } \\
\text { existing PPP }\end{array}$} & $\begin{array}{l}\text { Includes PPP from beyond originating sector and regional transboundary } \\
\text { environmental agreements. }\end{array}$ \\
\hline & & $\begin{array}{l}\text { Identifies and maximise potential aggregate, incremental and synergistic } \\
\text { beneficial impacts. }\end{array}$ \\
\hline & & $\begin{array}{l}\text { Identifies and mitigates potential aggregate, incremental and synergistic } \\
\text { negative impacts upon upstream and downstream receptors. }\end{array}$ \\
\hline & \multirow{2}{*}{$\begin{array}{l}\text { Necessary climate } \\
\text { change data } \\
\text { available and } \\
\text { knowledge gaps } \\
\text { clearly identified }\end{array}$} & $\begin{array}{l}\text { Potential impact of climate change upon infrastructure factored into design } \\
\text { requirements and power generation targets. }\end{array}$ \\
\hline & & $\begin{array}{l}\text { Synergistic impact of climate change and dams upon all water resource users } \\
\text { considered, including disaster risk level. }\end{array}$ \\
\hline & \multirow{2}{*}{$\begin{array}{l}\text { Ecosystem } \\
\text { indicators used for }\end{array}$} & Watershed degradation: Riverine and estuarine system health. \\
\hline & & Environmental Flow Requirements (EFR). \\
\hline
\end{tabular}




\begin{tabular}{|c|c|c|}
\hline & & Water quality. \\
\hline & $\begin{array}{l}\text { impacts with } \\
\text { thresholds and } \\
\text { absorption capacity } \\
\text { stated where } \\
\text { possible }\end{array}$ & $\begin{array}{l}\text { Social Indicators quantify secondary impact of environmental change upon } \\
\text { vulnerable populations. }\end{array}$ \\
\hline & $\begin{array}{l}\text { Sustainable } \\
\text { development options } \\
\text { and alternatives } \\
\text { Identified }\end{array}$ & $\begin{array}{l}\text { Range of reasonable alternatives developed and considered at the relevant } \\
\text { tier, including: } \\
\text { - demand management } \\
\text { - decentralised community level generation } \\
\text { - phasial siting } \\
\text { Extra studies utilised to meet information gaps in scenarios. }\end{array}$ \\
\hline & & $\begin{array}{l}\text { Potential decision outcomes clearly limited by pre-existing PPP and } \\
\text { transboundary agreements. }\end{array}$ \\
\hline & Transparent & $\begin{array}{l}\text { Stated equal weighting for biophysical, social and economic criteria. } \\
\text { Temporal dimensions considered, including lifecycle analysis and the } \\
\text { gestation of benefits and subsidies. }\end{array}$ \\
\hline & $\begin{array}{l}\text { framework criteria } \\
\text { used for assessing } \\
\text { and ranking }\end{array}$ & $\begin{array}{l}\text { Precautionary approach used for key irreversible impacts. Minimum } \\
\text { standards of high ecosystem functions outlined and committed to. Main stem } \\
\text { development avoided. }\end{array}$ \\
\hline & & Mitigation hierarchy used - avoid, reduce, offset. \\
\hline & & Distribution of benefits prioritises basic human needs. \\
\hline & Economic valuation & Social discount rates not too high \\
\hline & $\begin{array}{l}\text { and ecosystem } \\
\text { services employed } \\
\text { appropriately }\end{array}$ & $\begin{array}{l}\text { Volatility of energy and agriculture markets considered in Cost Benefit } \\
\text { Analysis (CBA) }\end{array}$ \\
\hline & Participatory & $\begin{array}{l}\text { Consultation plan engages all stakeholders on an ongoing basis from early } \\
\text { consideration of initial options to monitoring outcomes. Clear responsibilities } \\
\text { established for gathering, considering and responding to inputs. }\end{array}$ \\
\hline & & $\begin{array}{l}\text { Civil Society involved at relevant spatial scale in designing benefit sharing, } \\
\text { mitigation and compensation measures. }\end{array}$ \\
\hline & Power inequalities & $\begin{array}{l}\text { State engaged in broader electoral, judicial, transparency and corruption } \\
\text { reform initiatives. }\end{array}$ \\
\hline & $\begin{array}{l}\text { stakeholders } \\
\text { addressed through } \\
\text { accountability } \\
\text { enforcement } \\
\text { mechanisms }\end{array}$ & $\begin{array}{l}\text { Transparency established through rights to: } \\
\text { - Access information } \\
\text { - Substantive input } \\
\text { - } \text { Access dispute resolution mechanisms } \\
\end{array}$ \\
\hline & & $\begin{array}{l}\text { Budget and timeframe adequate for Environmental Management Plan (EMP) } \\
\text { implementation. }\end{array}$ \\
\hline & $\begin{array}{l}\text { Adequate capacity } \\
\text { held }\end{array}$ & $\begin{array}{l}\text { Authorities hold broad skills-set from a range of relevant disciplines. } \\
\text { Stakeholders provided with capacity and information required for full } \\
\text { engagement, including linguistic and literacy concerns. }\end{array}$ \\
\hline & & State maintains final overseer role and issues sectoral investment guidance. \\
\hline & & $\begin{array}{l}\text { Trans-boundary protocol for distribution of all benefits of mutual interest is } \\
\text { translated into national policies and implemented. }\end{array}$ \\
\hline & $\begin{array}{l}\text { institutions } \\
\text { established }\end{array}$ & $\begin{array}{l}\text { Independent regional coordinating body jointly funded. Additional financing } \\
\text { reduces capacity variance between sectors and countries. }\end{array}$ \\
\hline & & \\
\hline
\end{tabular}




\begin{tabular}{|c|c|c|}
\hline & \multirow[t]{3}{*}{$\begin{array}{l}\text { Roles and } \\
\text { responsibilities } \\
\text { coordinated }\end{array}$} & \begin{tabular}{|l} 
Institutional cross-overs mapped to avoid the duplication of roles for: \\
- Dividing benefits \\
- Creating EMP \\
- Mitigating impacts \\
- Generating and reviewing indicators \\
- Enforcing compliance.
\end{tabular} \\
\hline & & $\begin{array}{l}\text { Energy demand forecast body not responsible for supply infrastructure } \\
\text { decisions. }\end{array}$ \\
\hline & & $\begin{array}{l}\text { 'Sector-neutral' decision-making institution holds clear responsibility for } \\
\text { establishing basin-wide equitable water use through documented procedures. }\end{array}$ \\
\hline & & $\begin{array}{l}\text { Account for market incentive failures. Unsubsidised liability for failure to meet } \\
\text { targets. }\end{array}$ \\
\hline & for Independent & State maintains final overseer role and issues sectoral investment guidance. \\
\hline & $\begin{array}{l}\text { Power Producers } \\
\text { (IPPs) }\end{array}$ & $\begin{array}{l}\text { Independent regional coordinating body jointly funded. Additional financing } \\
\text { reduces capacity variance between sectors and countries. }\end{array}$ \\
\hline & & Recourse to mutually agreed, independent dispute resolution body available. \\
\hline \multirow{8}{*}{ 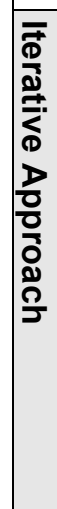 } & \multirow{3}{*}{$\begin{array}{l}\text { Flexible decisions } \\
\text { made, clearly stating } \\
\text { risks entailed by } \\
\text { gaps in knowledge }\end{array}$} & $\begin{array}{l}\text { Commitment to continuously improve knowledge generation, especially } \\
\text { climate change and hydrological modelling. }\end{array}$ \\
\hline & & Lower level EIAs required but avoid replicating prior EAs. \\
\hline & & $\begin{array}{l}\text { Commitment to organisational learning, analysing outcomes for consistency } \\
\text { with existing decisions and justifying instances of flexible interpretation. }\end{array}$ \\
\hline & \multirow{3}{*}{$\begin{array}{l}\text { M and E procedures } \\
\text { clearly set out and } \\
\text { observed }\end{array}$} & $\begin{array}{l}\text { Mandated actors formally review and monitor PPP outputs. } \\
\text { 5-10 year periodic project, basin, national and sectoral reports produced. }\end{array}$ \\
\hline & & SMART indicators used for consistent scheduled review. \\
\hline & & Accuracy of previous predictions and need for realignment clearly stated. \\
\hline & \multirow{2}{*}{$\begin{array}{l}\text { Additional provisions } \\
\text { for IPPs }\end{array}$} & $\begin{array}{l}\text { Development licenses harmonised across basins for maximum } 30 \text {-year term. } \\
\text { Social bonds stipulated. }\end{array}$ \\
\hline & & IPPs required to share sensitive commercial information with regulators. \\
\hline
\end{tabular}

Table 2: Summarised Conceptual Framework of Best Practice for SEA in the Koshi

Using the OECD's generic entry points for SEA (OECD 2006), twenty-six Policies, Plans and Programmes (PPP) ${ }^{1}$ relating to environmental planning and hydropower development were identified for review. In order to gain a full picture of the existing landscape, documents covering relevant lower tier activities, such as the assessment of cumulative effects in EIAs, were also included (Dusik et al 2003). Each policy document's legislative requirements were critically compared to each component of the CFW. The overall strength of all existing legislative requirements was then scored on an unweighted Likert scale depending on their breadth, depth and coherence (Figure 2).

1. Very weak: No, or virtually no elements of the best practice are present.

\footnotetext{
${ }^{1}$ For brevity, the term 'policies' or PPP shall be used interchangeably to refer to all documents reviewed despite having different specific meanings.

${ }^{3}$ Full criteria and results available upon request to the authors.
} 
2. Weak: Non-mandatory best practice is broadly incorporated in a mix of different documents.

3. Moderate: Best practice is fully included but is mainly non-mandatory and has little coordination between separate policy documents

4. Strong: All best practice is covered with binding requirements but not entirely coherently.

5. Exemplary: Existing documents work synergistically to establish binding requirements for all best practice criteria, exceeding it in some areas.

Figure 2: Likert scale for SEA requirements of existing policy documents (Bragagnolo and Geneletti 2012, Fischer 2010, Sadler 1998)

Document analysis was supplemented by twenty-one semi-structured primary interviews with twenty-four purposively sampled stakeholders (Table 3) (Fischer et al 2014). Informants were assigned to one of cultural theory's power groups (Gyawali 2003) which, whilst reductionist, provide useful shorthand for different stakeholders' approaches to policy-making.

\begin{tabular}{|rrr|}
\hline Organisation type & $\begin{array}{l}\text { Number } \\
\text { informants }\end{array}$ & Cultural Power Group \\
\hline Independent Power Producers & 3 & Commercial \\
Government representatives & 7 & Heirarchist \\
International Donors & 2 & Heirarchist \\
Research and Policy Institutions & 4 & Varies \\
Environmental Assessment Specialists & 5 & Commercial \\
Water rights campaigners & 3 & Activist \\
International NGOs & 3 & Activist \\
\hline
\end{tabular}

Table 3: Summary of interview informants by organisation type and cultural power group (Gyawali 2003)

No interviews were conducted with residents of the Koshi basin due to their inaccessibility; instead the views of civil society activists in Kathmandu were gained.

Questions focused upon how existing EA practice was viewed, whether it could be improved for any of the principal elements of best practice and the dimensions of the Koshi's trans-boundary issues. The content of transcripts and detailed notes were categorised by areas of best practice and other themes, and then analysed to identify patterns in responses. 


\section{Results and Analysis}

Overall, all areas of existing policy fall fairly short of best practice, highlighting the potential value of introducing SEA (Table 4). Whilst no features were entirely absent, they were usually only present as subsidiary elements of policies focusing on other areas.

Interviews provided a rich depiction of policymaking's current status on the ground, highlighting that in all areas, actual practice was weaker than the standards that were legally laid out. The main findings on how well existing policy and practice matches each of the CFW's four key priority areas were briefly summarised in turn.

\begin{tabular}{|c|c|c|c|c|}
\hline & $\begin{array}{l}\text { Main Features of existing } \\
\text { SEA Best Practice } \\
\text { guidelines }\end{array}$ & Qualitative Indicators & $\begin{array}{l}\text { Scores } \\
\text { by } \\
\text { Indicator }\end{array}$ & $\begin{array}{l}\text { Aggregate } \\
\text { Scores }\end{array}$ \\
\hline \multirow{9}{*}{ 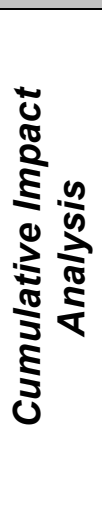 } & \multirow{3}{*}{$\begin{array}{c}\text { Spatial Scale and Policy } \\
\text { Level }\end{array}$} & Broader Policies considered & 3 & \multirow{3}{*}{2.7} \\
\hline & & Benefits maximised & 3 & \\
\hline & & Negative Impacts Managed & 2 & \\
\hline & \multirow[b]{2}{*}{ Climate Change } & Impact upon infrastructure & 3 & \multirow[b]{2}{*}{3} \\
\hline & & $\begin{array}{r}\begin{array}{r}\text { Synergistic Impact upon water } \\
\text { resources }\end{array} \\
\end{array}$ & 3 & \\
\hline & \multirow{4}{*}{ Ecosystem Indicators } & Watershed degradation & 2 & \multirow{4}{*}{1.75} \\
\hline & & $\begin{array}{r}\text { Stated Environmental Flow } \\
\text { Requirement }\end{array}$ & 1 & \\
\hline & & Water quality & 3 & \\
\hline & & Social Indicators & 1 & \\
\hline \multirow{6}{*}{ 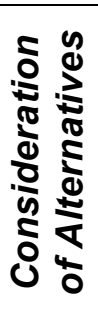 } & \multirow{2}{*}{$\begin{array}{c}\text { Sustainable Development } \\
\text { Focus }\end{array}$} & Scenario Generation & 2 & \multirow[b]{2}{*}{2.5} \\
\hline & & Policy Hierarchy & 3 & \\
\hline & \multirow{4}{*}{ Decision Making Criteria } & Equal 'pillars' & 3 & \multirow{4}{*}{3} \\
\hline & & Precautionary principle & 1 & \\
\hline & & Mitigation hierarchy & 4 & \\
\hline & & Benefit distribution & 4 & \\
\hline \multirow{8}{*}{ 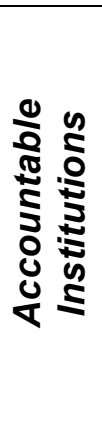 } & \multirow{2}{*}{ Participatory Process } & Clear Plan & 4 & \multirow{2}{*}{4} \\
\hline & & Civil Society role(s) & 4 & \\
\hline & \multirow{4}{*}{$\begin{array}{c}\text { Accountability } \\
\text { Enforcement mechanisms }\end{array}$} & Broader State Reform & & \multirow{4}{*}{1.7} \\
\hline & & Transparency & 2 & \\
\hline & & $\begin{array}{l}\text { Prior Informed Consent for } \\
\text { marginalised stakeholders }\end{array}$ & 1 & \\
\hline & & Auditing and Monitoring & 2 & \\
\hline & \multirow{2}{*}{ Adequate capacity } & Resources & & \multirow{2}{*}{2} \\
\hline & & Skills & 1 & \\
\hline
\end{tabular}




\begin{tabular}{|c|c|c|c|c|}
\hline & & Information available & 3 & \\
\hline & \multirow{3}{*}{$\begin{array}{l}\text { Coordinated roles and } \\
\text { responsibilities }\end{array}$} & Sectoral Delineation & 4 & \multirow{3}{*}{4} \\
\hline & & Conflict of Interests avoided & 4 & \\
\hline & & Coordinating Body & 4 & \\
\hline & \multirow{2}{*}{ Private Provisions } & Market Factors & 2 & \multirow{2}{*}{3} \\
\hline & & State overview & 4 & \\
\hline & \multirow{3}{*}{ Transboundary bodies } & Benefit Distribution & 3 & \multirow{3}{*}{3.3} \\
\hline & & Coordinating body & 3 & \\
\hline & & Dispute Resolution Mechanism & 4 & \\
\hline \multirow{6}{*}{ 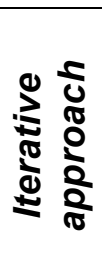 } & \multirow{3}{*}{ Decision Flexibility } & Ongoing Knowledge Generation & 3 & \multirow{3}{*}{3.3} \\
\hline & & Tiered EA & 4 & \\
\hline & & Ongoing Learning & 3 & \\
\hline & \multirow{3}{*}{$\mathrm{M}$ and $\mathrm{E}$ procedures } & Formal Review Procedure & 4 & \multirow{3}{*}{4} \\
\hline & & Clear Indicators & 4 & \\
\hline & & Conditional Terms of Operation & - & \\
\hline
\end{tabular}

Table 4: Scores for existing policy's alignment to CFW of SEA Best Practice for the Koshi ${ }^{3}$

\section{Cumulative impacts}

There was broad agreement that a lack of strategic hydropower coordination was a concern. One EA expert stated 'this is urgent ... what will it entail if we build $30,000 \mathrm{MW}$ in Nepal in the next 30 years? ... There has not been that kind of assessment'. Independent Power Producers (IPPs) operating in the Koshi do not share planning materials and policy only requires EIAs to consider impacts on directly cascading hydropower projects. As in other areas of intensive development, SEA was seen as potentially offering particular support to the coordination of infrastructure, such as storage facilities, roads and transmission lines (Bragagnolo et al 2012, Canter and Ross 2010, Fischer et al 2014).

Many informants felt that SEA could help identify and value basin-wide ecosystem indicators such as sediment releases, fish populations, flow rates and social income levels, as well as identifying biological thresholds and controls such as development phases and zones. Such measures could underpin an integrated Water Resource Management (IWRM) approach and inform an increase in existing Environmental Flow

\footnotetext{
${ }^{3}$ Full criteria and results available upon request to the authors.
} 
Requirements (GoN 2001, Geneletti 2015).

Planning for the uncertain and complex effects of climate change on the Koshi region are another key area to which informants believed SEA could contribute (EC 2013). Specifically, following the 2015 earthquake and 2008 avulsion, SEA could inform the current debate over the potential for dams to provide flood control (Das and Bhuyan 2012, ICIMOD 2012, Harshadeep 2011, Sharma et al 2009).

\section{Consideration of alternatives}

Current policy gaps indicate that SEA could also improve the consideration of alternatives in hydropower planning, but the gap between existing and best practice was extensive in this area. The Nepali government is increasingly focused upon approving larger hydropower installations solely on the basis of economic criteria such as the price per K/W (Dixit and Basnet 2005, Dixit et al 2004, Gyawali 2008). The precautionary principle and a clear definition of 'significant' policy effects are particularly conspicuous for their absence in any strategic documents and demand mitigation is only referred to in relation to combating of power leakages (Dixit and Basnet 2005). Instead, policy makers aim to develop out of the current infrastructure problems by creating a domestic industrial market that would generate ongoing demand for hydropower (GoN 2001). All respondents, including activists, therefore stressed a desire for 'no bad dams' as opposed to 'no dams' and pragmatic 'grey' instead of 'green' environmentalists. One government official also claimed that the environmental losses risked by not conducting a thorough SEA would be outweighed by the additional income generated from the early commissioning of hydropower stations (Bhatt and Khanal 2010, Dalal-Clayton and Sadler 2005). 


\section{Iterative approach}

The region has made some moves towards tiered strategic-level assessment through Strategic Basin Assessments ${ }^{4}$ a Hydropower Sectoral Environmental Assessment and a National Water Plan SEA (GoN 1997, Imran et al 2006, Posas and Sanchez-Triana 2012). However, these exercises have been disjointed across a twenty-year period and failed to effect wider decision-making processes (Erlewein 2013, Hirji and Davis 2009, Slootweg 2009). The National Water Resource Strategy, National Water Plan and Koshi Basin Strategic Management Plan are the only PPPs which Nepal has developed in a coordinated manner, refining previous policy decisions at each sequentially lower tier. These documents also held the only official commitments to institutional accountability through the use of SEA and the creation of River Basin Organisations (RBOs). Unfortunately, as in other contexts, the weakness of existing institutions and the shortterm priority of energy generation has prevented the realisation of such flexible and knowledge-based approaches (Lobosa and Partidario 2014, Victor and Agamuthu 2014).

\section{Institutional Accountability and Decision-making}

Lack of institutional accountability and transparency are seen as the main obstacles to the implementation of SEA. However, despite subordinating SEA in favour of unrestricted energy generation, the hydropower sector's development has also been perpetually undermined by state-state and state-civil society conflicts, which prevent broad-based planning and open dialogue. All actors separately expressed interest in SEA improving these institutional procedures, but as open information sharing is so central to SEA's effectiveness it would also currently meet considerable challenge from

\footnotetext{
${ }^{4}$ Strategic Basin Assessments, Sustainability Assessments and Sectoral Environmental Assessments use similar characteristics. For simplicity SEA will be used through this article.
} 
stakeholders who prefer maintaining their entrenched positions to negotiating genuine concessions within a formal SEA framework (Erlewein 2013, Jones et al 2012).

SEA presents the opportunity to consult communities at a much earlier stage of planning than EIA but basin-wide consultation is a logistical challenge (Andrade and Dos Santos 2015, Fischer et al 2014) and one government official considered it to be 'pointless' due to high levels of outward migration from rural communities. The engagement of preexisting community networks, such as water users groups, was seen as a practical approach but many informants saw Kathmandu-based social activists as trying to become the default representatives of the 'voiceless masses' or even accused them of using their position to block necessary development. One government official viewed a researcher for this paper as being 'contaminated' for having even spoken to certain activists. Many activists in turn are also not focused upon compromise; on referring to 'bad' hydropower schemes one prolific activist stated "every time the snake raises its head, we'll squash it".

Within the government itself, hydropower and environmental planning are already fragmented between numerous ministries. The Ministry of Energy, is responsible for reviewing project-monitoring reports, The Ministry of Science Technology and Environment (MOSTE) conducts project audits and the Water and Energy Commission Secretariat (WECS) holds nominal responsibility for policy level reviews. Low capacity and poor communication often reduces many of these processes into 'box ticking' exercises.

Informants nominated six different bodies, or a combination of them, as appropriate lead agencies for SEA. In this context, one activist described SEA as 'an absolute orphan ... no one wants to own it so it's pointless'. Even ministries that stated a willingness to lead 
on SEA are hampered by intra-governmental conflict; the MOSTE was described as an 'interloper' in the Ministry of Forestry and Soil Conservation, whilst WECS is seen as a think tank and 'political dumping ground'.

Beyond these numerous domestic barriers, involving both India and Nepal in a transboundary SEA of the Koshi basin presents additional challenges. Since the Koshi Treaty of 1954 , commitments to share the down-stream benefits of storage projects on a rights-basis have not been realised (Salman and Uprety 2011). Nepali commentators accuse India of refusing to monetise the downstream flood regulation and irrigation benefits that it receives from Nepali dams and of bribing Nepali officials and activists to reduce the possibility of a 'united front' in negotiations. Nepal wishes to avoid becoming an Indian 'protectorate' by entering into similar agreements to Bhutan, however, as the current fuel blockade cripples its economy, it is clear the country lacks a viable alternative energy trading partner (Dhungel 2008, MOWR 2011, Rahaman, 2012).

Given institutional weakness at all levels, most informants expected that SEA will remain something which is only conducted for, and by, international donors and consultants. A long period of political stability or the emergence of a charismatic leadership who can foment a 'critical mass' of support behind SEA's benefits were seen as prerequisites for its expanded use. At the time of writing, the aftermath of the 2015 Earthquake and ongoing constitutional conflict make this an unlikely possibility (Kathmandu Post 2016). Paradoxically however, achieving such conditions would raise sequentialist concerns over how fast they would remove barriers to hydropower's development. Given the 'power imperative', there is a strong likelihood that political stability would facilitate the implementation of the numerous projects which have been licensed across the Koshi (Figure 1) before an SEA is conducted to identify their irreversible cumulative 
environmental impacts.

\section{Moving SEA forward in the Koshi Basin: from principles to practice}

Having analysed the region's policymaking landscape, this paper has established that existing strategic decisions relating to hydropower in the Koshi river basin are subject to major failings. Applying the principles for good SEA practice which this paper has conceived for the Koshi, could help tackle the region's energy deficit in a sustainable manner. Whilst previous attempts to legislate SEA from the centre have stalled, and existing institutional problems merit a cautionary approach, such issues have been overcome in similar contexts (Bina 2008, Fischer et al 2014). Instead, a more flexible and dynamic approach should be pursued to develop hybrid structures that can realise SEA's benefits. Particular opportunities lie in the facilitation of shared learning and understanding between stakeholders (Gazola et al 2011, Lobosa and Partidario and Sheate 2013, Partidario 2014, Partidario 2015, Tetlow and Hanusch 2012, Victor and Agamuthu 2014).

Three initial moves are recommended:

\section{Identify a lead agency in Nepal}

Strong ownership of the concept of SEA by one or more empowered actors is a prerequisite for its benefits to be realised. WECS has shown the greatest engagement with SEA as an IWRM tool thus far but a commitment to broad-based participation would be equally as important as technical capacity (Fischer et al 2014). An ideal mandate for 
SEA would come from a Koshi RBO; this could be established by WECS with the support and involvement of MOSTE, civil society and IPPs.

\section{Engage on a Transboundary level}

Ongoing disputes may currently render a full scale transboundary SEA unfeasible, however initiating a non-binding process could help resolve some tensions by transparently accounting for the cumulative benefits and costs of hydropower (Partidario 2015). The involvement of a respected neutral body, similar to the Mekong River Commission, would be essential (ICEM 2010). As a leading Himalayan research agency, ICIMOD could fill this role, and is already engaged in transboundary management of the basin's water resource through the ongoing Koshi Basin Programme (KBP) (ICIMOD 2012).

\section{Pilot a focused SEA}

It would be beneficial to focus an initial WECS-led Koshi SEA on areas with fairly broad stakeholder support and interest such as cumulative effects, particularly climate change. Any such initiative should avoid accusations of being overly donor-led by engaging a broad range of stakeholders who have a genuine interest in the processes' outcomes.

This research has identified key considerations and potential next steps for SEA and hydropower planning in the Koshi Basin. We would recommend that these are considered and discussed by all of the stakeholder groups who engaged with the study as well as additional actors, in particular local communities and relevant Indian institutions. The huge scale of the Koshi Basin and the complexity of hydropower planning procedures mean that some areas were omitted from this paper and further 
discussion could also benefit from more comprehensive research on EA's use in the region. This review has also identified several parallels between the Koshi context and wider current SEA theory, in particular the challenges of integration into complex decision making institutions and the resultant success of more flexible non-legislative approaches. 


\section{References}

Acharibasama J, Noblea B (2014) 'Assessing the impact of strategic environmental assessment'. Impact Assessment and Project Appraisal Vol 32, 3

Andrade A, dos Santos M (2015) Hydroelectric plants environmental viability: 'Strategic

environmental assessment Application in Brazil'. Renewable and Sustainable Energy Reviews Vol 52; 1413-1423

Bhatt RP and Khanal SN (2010) 'Environmental impact assessment system and process: A study on policy and legal instruments in Nepal'. African Journal of Environmental Science and Technology, Vol 4(9), 586-594

Bina O (2008) 'Context and Systems: Thinking More Broadly About Effectiveness in Strategic Environmental Assessment in China'. Environmental Management; Vol. 42, (4), $717-733$

Bragagnolo C, Geneletti D (2012) 'Addressing cumulative effects in Strategic Environmental Assessment of spatial planning'. Pubblicazioni II Centro Studi di Estimo e di Economia Territoriale Vol 60, Firenze University Press

Bragagnolo C, Fischer T, Geneletti D (2012) 'Cumulative effects in strategic environmental assessment of spatial plans - evidence from Italy and England'. Impact Assessment and Project Appraisal, 30(2): 100-110. 
Canter L, Ross B, (2010) 'State of practice of cumulative effects assessment and management: the good, the bad and the ugly'. Impact Assessment and Project Appraisal, 28 (4), $261-268$.

Cherpa A, Wattb A, Vinichenkoc V (2007) 'SEA and strategy formation theories: From three Ps to five Ps'; Environmental Impact Assessment Review, Vol 27, Issue 7, 624644

Das P, Bhuyan H (2012) 'Effectiveness of Flood Mitigation Infrastructure in Addressing Water Hazards: Cases in India and Nepal' pp43-55 In: Pradhan, NS; Khadgi, VR; Schipper, L; Kaur, N; Geoghegan, T (2012) Role of Policy and Institutions in Local Adaptation to Climate Change - Case studies on responses to too much and too little water in the Hindu Kush Himalayas. Kathmandu: ICIMOD

Dalal-Clayton B, Sadler B (2005) Strategic Environmental Assessment: A Sourcebook and Reference Guide to International Experience. International Institute for Environment and Development (IIED), London

Dhungel D (2008) 'A Historical Eyeview' In Dhungel D and Pun S (eds) Nepal-India Water Resources Relationship: Challenges, Springer

Dusik J, Fischer T, Sadler B (2003) Benefits of a Strategic Environmental Assessment, UNDP/REC

Dixit, A Adhikari, P Bisangkhe, S (2004) Constructive dialogue on dams and development in Nepal, IUCN, Kathmandu 
Dixit A, Basnet S (2005) Recognising Entitlements and Sharing Benefits: Emerging Trends in Nepal's Hydropower Terrain. IUCN

EC (2013). Guidance on Integrating Climate Change and Biodiversity into Strategic Environmental Assessment. European Commission.

Erlewein A (2013) 'Disappearing rivers — The limits of environmental assessment for hydropower in India'. Environmental Impact Assessment Review; 43:135-143

Fischer T (2010) 'Reviewing the quality of strategic environmental assessment reports for English spatial plan core strategies'. EIA Review, 30(1): 62-69. 'Results and Analysis' section.

Fischer T, Onyango V (2012) 'Strategic environmental assessment-related research projects and journal articles: an overview of the past 20 years'. Impact Assessment and Project Appraisal, 30:4.

Fischer T et al (2014) Environmental Impact Assessment Handbook for Pakistan. Islamabad: IUCN Pakistan.

Fischer T, Phylip-Jones J (2015) Strategic environmental assessment for wind energy planning: Lessons from the United Kingdom and Germany Environmental Impact Assessment Review 50 
Gazzola P, Jha-Thakur U, Kidd S Peel D, Fischer T, (2011) ‘Enhancing Environmental Appraisal Effectiveness: Towards an Understanding of Internal Context Conditions in Organisational Learning'; Planning Theory \& Practice; Vol 12; 2

Geneletti D (2015) 'A Conceptual Approach to Promote the Integration of Ecosystem Services in Strategic Environmental Assessment'. J. Env. Assmt. Pol. Mgmt., 17

Government of Nepal, Ministry of Water and Power (1975) Revised Agreement between His Majesty's Government of Nepal and The Government of India on The Kosi Project Nepal

Government of Nepal (1992) Water Resources Act, Nepal Gazette, 1992

Government of Nepal (1997) Environment Protection Act, Act No 24 of the year 2053 (1997), Nepal Gazette, May 1997

Government of Nepal (1999) Environment Protection (First Amendment) Rules 2055.12.22 (April I5, 1999), Nepal Gazette, April 1999

Government of Nepal, Ministry of Water Resources (2001) The Hydropower Development Policy, Nepal

Government of Nepal, Water and Energy Commission (2002) Water Resource Strategy, Nepal

Government of Nepal, Water and Energy Commission (2005) National Water Plan, 
Nepal

Government of Nepal, Ministry of Environment, (2010) National Adaptation Programme of Action (NAPA) to Climate Change, Nepal

Government of Nepal, Water and Energy Commission (2010) Koshi River Basin Management Strategic Plan (2011-2021) WWF, Nepal

Government of Nepal (2011) Climate Change Policy, Nepal

Gyawali, D (2003) Rivers, Technology and Society: Learning the Lessons of Water Management in Nepal, Zed Books, New York

Gyawali D (2008) ‘Epilogue (Re-imagining Nepal’s Water: Institutional Blind Spots, Developmental Blind Alleys and the Lessons of the Century Past)' In Dhungel D and Pun S (eds) Nepal-India Water Resources Relationship: Challenges, Springer

Harshadeep N (2011) The Ganges Basin: An Overview for the Ganges Strategic Basin Assessment. Powerpoint Presentation, World Water Week, Stockholm International Water Institute

Hirji R and Davis R (2009) Strategic Environmental Assessment: Improving Water Resources Governance and Decision-making: Main Report, Water Sector Board Discussion Series Paper no. 12, The World Bank, Washington, DC 
ICEM, 2010, Mekong River Commission Strategic Environmental Assessment (SEA) of hydropower on the Mekong mainstream: summary of the final report, Hanoi, Vietnam

Imran T, Storm P and van Leeuwen T, (2006) Nepal Power Development Project Sectorial Environmental Assessment Training session: Strategic Environment Assessment in the Energy Sector, March 2006, Kathmandu

International Association for Impact assessment (2002) Strategic Environmental Assessment Performance Criteria, Special Publications Series 1, IAIA

International Centre for Integrated Mountain Development (2012) Koshi Basin Programme - Phase 1: Inception Workshop Report, 3-5 September 2012, ICIMOD, Kathmandu

Japan International Cooperation Agency (1985) Master Plan Study on the Koshi River Water Resources Development JICA, Kathmandu

Jha-Thakur U, Gazzola P, Peel D, Fischer T, Kidd S (2009) 'Effectiveness of strategic environmental assessment - the significance of learning'. Impact Assessment and Project Appraisal, 27:2, 133-144,

Jones H, Jones N, Shaxson L and Walker D (2012) Knowledge, policy and power in international development: A practical guide Policy Press, London

Khangram S (2005) Dams and Development: Transnational Struggles for Water and Power, Cornell University Press 
Kathmandu Post (2016) 'Norways Statkraft pulls plug on Tamakoshi-IIl'. Kathmandu Post, January 13, 2016.

Lobosa V, Partidario M (2014) 'Theory versus practice in Strategic Environmental Assessment (SEA)' Environmental Impact Assessment Review Volume 48, 34-46

OECD (2006) Applying Strategic Environmental Assessment - Good Practice Guidance for Development Co-operation. DAC Guidelines and Reference Series, OECD Publishing.

Partidario M (2015) 'A Strategic Advocacy Role in SEA for Sustainability'. Journal of Environmental Assessment Policy and Management; 17(01)

Partidario M, Sheate W (2013) 'Knowledge brokerage-potential for increased capacities and shared power in impact assessment'. Environmental Impact Assessment Review (39:26-36.

Posas P and Sánchez-Triana E (2012) 'World Bank SEA Experience in South: from Impact-centered to policy approaches' in Loayza $F$ (ed) Strategic Environmental Assessment in The World Bank: Learning from Recent Experiences and Challenges, World Bank

Pun S (2008) 'Power Trading' In Dhungel D and Pun S (eds) Nepal-India Water Resources Relationship: Challenges, Springer 
Rahaman, M.M. (2012) 'Hydropower ambitions of South Asian nations and China: Ganges and Brahmaputra Rivers basins', In International Journal of Sustainable Society, Vol. 4, Nos. 1/2, pp.131-157.

Sadler, B (1998) 'Ex post evaluation of the effectiveness of environmental assessment', in Porter A and Fittipaldi J (eds.) Environmental Methods Review: Retooling Impact Assessment for the New Century, International Association for Impact Assessment, Fargo, USA, 30-40

Salman, M and Uprety, K (2011): Legal aspects of sharing and management of transboundary waters in South Asia: preventing conflicts and promoting cooperation, Hydrological Sciences Journal, 56:4, 641-661

Sharma, E; Chettri, N; Tse-ring, K; Shrestha, AB; Mool, PK; Eriksson, M (2009) Climate change impacts and vulnerability in the Eastern Himalayas. Kathmandu, Nepal: ICIMOD

Slootweg, R (2009) Integrated Water Resources Management and Strategic Environmental Assessment joining forces for climate proofing: Briefing paper by the Cooperative Programme on Water and Climate (CPWC) and the Netherlands Commission for Environmental Assessment (MER) for the $5^{\text {th }}$ World Water Forum

Tetlow M, Hanusch M (2012) 'Strategic environmental assessment: the state of the art'. Impact Assessment and Project Appraisal,30:1, 15-24 
Uprety BK (2008) 'A Decade of Legally Practicing the Environmental Assessment Tool' in Hydro Nepal Journal of Water, Energy and Environment Issue No. 2 January, 2008 p $9-12$

Victor D, Agamuthu P (2014) 'Policy trends of strategic environmental assessment in Asia'. Environmental Science \& Policy 08; 41.

World Commission on Dams (2000) Dams and Development: A New Framework for Decision-Making. A Report of the World Commission on Dams, Earthscan Publications Ltd, London and Sterling VA.

World Bank (2008) Strategic Environmental Assessment in Policy and Sector Reform: Conceptual Model and Operational Guidance, World Bank University of Gothenburg, Swedish University of Agricultural Sciences, Netherlands Commission for Environmental Assessment, World Bank 